\title{
Taxation and Budget Reform Commission (TBRC) Constitutional Amendment 5: Eliminating State Required School Property Tax and Replacing with Equivalent State Revenues to Fund Education ${ }^{1}$
}

Rodney L. Clouser²

This amendment was removed from the November 2008 ballot by the Florida Supreme Court. FE744 will be maintained on the EDIS website through December 31, 2008, and then archived for historical purposes.

Authors Note: On Thursday, August 14, 2008, a Leon County Circuit Court Judge ordered the Florida Secretary of State to remove Amendment 5 from the November 2008 ballot. The defendant in this case (Florida Department of State) has indicated that they will appeal this summary judgment decision. It is anticipated that the final decision, if Amendment 5 will appear on the fall 2008 ballot, will be made at a later date by the Florida Supreme Court.

A series of 16 fact sheets has been written on statutory and constitutional proposals adopted by the Taxation and Budget Reform Commission (TBRC). The publications in this series can be accessed at http://edis.ifas.ufl.edu. Fact sheets FE733 through FE741 address statutory changes and fact sheets FE742 through FE748 address constitutional amendments. These fact sheets should not be considered as an all-inclusive assessment of the statutory or constitutional changes recommended by the Taxation and Budget Reform Commission. Some details of proposed changes may not have been discussed due to space limitations. These fact sheets are not intended as a replacement for personal knowledge about actual or proposed changes but are a guide to inform the public on the issues.

\section{Introduction}

According to Article XI, Section 6 of the Florida Constitution, "Beginning in 2007 and each twentieth year thereafter there shall be established a taxation and budget reform commission." The Taxation and Budget Reform Commission (TBRC) is charged with the following:

examine the state budgetary process, the revenue needs and expenditure processes of the state, the appropriateness of the tax structure of the state, and governmental productivity and efficiency; review policy as it

1. This is EDIS document FE744, a publication of the Food and Resource Economics Department, Florida Cooperative Extension Service, Institute of Food and Agricultural Sciences, University of Florida, Gainesville, FL. Published July 2008. Please visit the EDIS website at http://edis.ifas.ufl.edu.

2. Rodney L. Clouser, professor and extension public policy specialist of the Food and Resource Economics Department, Florida Cooperative Extension Service, Institute of Food and Agricultural Sciences, University of Florida, Gainesville, FL.

The Institute of Food and Agricultural Sciences (IFAS) is an Equal Opportunity Institution authorized to provide research, educational information and other services only to individuals and institutions that function with non-discrimination with respect to race, creed, color, religion, age, disability, sex, sexual orientation, marital status, national origin, political opinions or affiliations. U.S. Department of Agriculture, Cooperative Extension Service, University of Florida, IFAS, Florida A. \& M. University Cooperative Extension Program, and Boards of County Commissioners Cooperating. Larry Arrington, Dean 
relates to the ability of state and local government to tax and adequately fund governmental operations and capital facilities required to meet the state's needs during the next twenty-year period; determine methods favored by the citizens of the state to fund the needs of the state, including alternative methods for raising sufficient revenues for the needs of the state; determine measures that could be instituted to effectively gather funds from existing tax sources; examine constitutional limitations on taxation and expenditures at the state and local level; and review the state's comprehensive planning, budgeting and needs assessment processes to determine whether the resulting information adequately supports a strategic decision-making process.

The TBRC can make statutory recommendations to the Florida Legislature and directly place proposed constitutional amendments on the ballot for approval or rejection by Florida voters.

Fact sheets in this series will present information on constitutional amendments the TBRC has placed on the fall 2008 general election (2008 November presidential election) ballot. The commission was charged with holding public meetings to carry out their responsibilities and has been meeting since March of 2007. The committee concluded their work and transmitted their proposed constitutional amendments to the Florida Secretary of State on April 28,2008 . All the proposed constitutional amendments required an affirmative vote of at least two-thirds of the voting members of the commission (17 members). In total, the TBRC approved eleven constitutional proposals. The committee combined these eleven proposals into seven constitutional amendments. The amendments passed by the TBRC will be numbered Amendments 3 through 9 on the fall ballot (Amendments 1 and 2 are reserved for two other 2008 amendment proposals, one approved by the legislature and the other a citizen initiative).

The TBRC amendments placed on the 2008 general election ballot are listed by ballot title below:
- Amendment 3: Changes and Improvements Not Affecting the Assessed Value of Residential Real Property

- Amendment 4: Property Tax Exemption of Perpetually Conserved Land; Classification and Assessment of Land Used for Conservation

- Amendment 5: Eliminating State Required School Property Tax and Replacing with Equivalent State Revenues to Fund Education

- Amendment 6: Assessment of Working Waterfront Property Based upon Current Use

- Amendment 7: Religious Freedom

- Amendment 8: Local Option Community College Funding

- Amendment 9: Requiring 65 Percent of School Funding for Classroom Instruction; State's Duty for Children's Education

Each fact sheet in this series will provide details regarding one of the amendments, submitted to the Secretary of State, in the order they will appear on the ballot (Amendment 3, Amendment 4, Amendment 5, Amendment 6, Amendment 7, Amendment 8, and Amendment 9).

\section{Proposed Amendment 5}

When people go to their polling places in November 2008, they will see information on the amendment, references to the portion of the constitution that will be altered, sponsor of the amendment, the ballot title, and the ballot summary. The information for Amendment 5 will be similar or identical to the following and the ballot title and ballot summary are direct quotes:

Proposed Constitutional Amendment No. 5: ARTICLE VII, SECTIONS 4, 9, AND 19; ARTICLE XII, SECTION 28 (Taxation and Budget Reform Commission)

Ballot Title: ELIMINATING STATE REQUIRED SCHOOL PROPERTY TAX AND REPLACING WITH EQUIVALENT STATE REVENUES TO FUND EDUCATION 
Ballot Summary: Replacing state required school property taxes with state revenues generating an equivalent hold harmless amount for schools through one or more of the following options: repealing sales tax exemptions not specifically excluded; increasing sales tax rate up to one percentage point; spending reductions; other revenue options created by the legislature. Limiting subject matter of laws granting future exemptions. Limiting annual increases in assessment of non-homestead real property. Lowering property tax millage rate for schools.

\section{Effect of Amendment 5}

There are four primary components of Amendment 5:

1. Non-homestead property tax assessments could not increase more than $5 \%$ of the preceding year's assessment.

2. The tax millage (the tax rate per $\$ 1000$ of taxable value) for school operating funds would be limited to five mills ( $\$ 5$ per $\$ 1000$ of taxable value).

3. All laws creating a sales tax exemption would be limited to the single subject of the exemption, a legislative decision that the exemption "advances or serves the public purpose of encouraging economic development and competitiveness; supporting educational, governmental, literary, scientific, religious, or charitable initiatives or organizations securing tax fairness."

4. The legislature would be prohibited from requiring local school districts to levy "an ad valorem tax as a required local effort."

Under current law, non-homestead property tax assessments cannot increase more than $10 \%$ of the prior year's assessment. It is notable that the TBRC recommended reducing this to no more than $5 \%$ of the preceding year's assessment. Why is this a noteworthy change? The current $10 \%$ cap was just passed in January of 2008 as part of Amendment 1 voted on by state residents during the presidential primaries. The TBRC recommendation brings the maximum yearly increase for non-homesteaded property more in line with the limits for homesteaded property annual-assessed value increases (3\% maximum in any year). If the amendment is passed, this change takes effect on January 1, 2009.

Under current law, school boards can levy ad valorem property taxes for operating purposes at the level of ten mills. The change proposed here would reduce this to five mills. However, this limit would not apply to "taxes levied for the payment of bonds and taxes levied for periods not longer than two years when authorized by vote of the electors." If the amendment were passed, this change would take effect on January 1, 2010.

The third component of Amendment 5 is "the single subject of a single exemption" requirement. This would apply to all new sales tax exemptions considered by the legislature. Additionally, the proposed amendment requires a legislative finding that any new exemption supports or advances a public purpose in the areas of: (1) encouraging economic development and competitiveness, (2) supporting educational, governmental, literary, scientific, religious, or charitable initiatives or organizations, or (3) securing tax fairness.

The fourth and final component of the proposed amendment is forbidding the legislature from requiring the levy of a required local effort to participate in the Florida Education Finance Program (FEFP). Under current law, the legislature determines the amount of taxes that are to be collected through local ad valorem taxes by the local school board. This local ad valorem tax levy is required by the local school district, or the district is ineligible to receive state funding through the FEFP. This "required local effort " (RLE) is significant; it is estimated statewide at just under $\$ 8$ billion for fiscal year 2007-2008. This is slightly over $25 \%$ of all local government ad valorem tax collections in the state.

Amendment 5 proposes alternatives for the legislature to replace the RLE beginning in fiscal year 2010-2011. The legislative alternatives would be:

1. Repeal some of the state's current sales tax exemptions that do not advance or serve a public purpose. However, the proposed amendment specifically forbids repeal of current exemptions of "food; prescription drugs; health services; 
charitable organizations; religious organizations; residential rent, electricity, and heating fuel; sales of tangible personal property purchased for resale or imported, produced, or manufactured in this state for export; sales of real property; and sales of intangible personal property."

2. Increase the state sales and use tax by $1 \%$ (e.g., from $6 \%$ to $7 \%$ ) over the existing rate in effect on January 6, 2009.

3. Reduce funding for other state budget items or use "revenue increases resulting from economic growth attributable to lower property taxes" to replace the RLE.

4. Use other established or created revenues to fund the RLE.

The amendment also would establish an "education hold harmless amount." The hold harmless amount is defined by the TBRC as the amount appropriated by the state in (general appropriations) fiscal year 2010-2011, which must not be lower than the amount appropriated in fiscal year 2008-2009 by the FEFP, as increased by the average historical growth in these funds in fiscal years 2006-2007 and 2007-2008.

\section{Impact of Amendment 5}

The many changes associated with this amendment and the different dates proposed for each to take effect make this amendment complex. Some of the proposed changes have no fiscal impacts. For example, the change proposed regarding the "single subject, single exemption rule" with a legislative finding of serving or advancing a public purpose has no immediate fiscal impact. Fiscal impacts will only happen if a new exemption is passed by the legislature.

The portion of the amendment reducing the growth in assessed value for non-homesteaded property will have fiscal impacts if passed but not on schools. The previous amendment (January 2008) where the assessed value increase of $10 \%$ was passed did not apply to schools and the proposed limit of 5\% per annum would not apply to schools either. This is not true for other units of local government such as counties, municipalities, and special districts. In the analysis of the previous amendment when the increase was limited to $10 \%$, it was estimated, compared to the current law, that the cost would be about $\$ 1.16$ billion over a four-year period. Since Amendment 5 proposes to make the maximum growth in assessed value even lower, the fiscal impact of the amendment for local government units will be even higher. However, since the housing market has been depressed over the past several months, this impact will be less, at least initially, compared to earlier years when Florida housing values were increasing in double digits on a yearly basis.

The elimination of the required local effort (RLE) would reduce property taxes just under $\$ 8$ billion, and it is estimated that it would reduce the average homeowners tax bill by about $25 \%$. This impact, though, is dependent on how the legislature replaces the funds previously raised by the RLE. If the general sales tax is raised by $1 \%$, then everyone will pay more for items purchased that are not exempt from the sales and use tax. If the legislature creates or establishes new revenue sources to replace the RLE, then people may pay more elsewhere. The same is true if the legislature repeals sales tax exemptions; people would end up paying more in sales taxes. Few people have commented on the fact that Florida residents who itemize deductions on federal tax returns would lose a portion of the property tax deduction, meaning that they would pay more federal taxes. In addition, the sales tax deduction on federal returns that is now available to state residents is not guaranteed in the future (currently it is being extended on a year-by-year basis).

Business interests have expressed concern about the amendment, citing the difficulty in business decision making when the state's future tax structure is uncertain. Business interests, as well as others, have also expressed concern that the amendment is a "back door" attempt to repeal exemptions or to institute a tax on services. They base this concern on the fact that it is estimated that a $1 \%$ increase in the sales tax, from $6 \%$ to $7 \%$, would only generate about $\$ 4$ billion of the $\$ 8$ billion needed to replace the RLE (the amount needed will likely be greater than $\$ 8$ billion when the historical growth amount is factored in). There is concern that the legislature will decrease 
funding to various organizations, in effect reducing programs and services. Schools have expressed concern because they fear the legislature will not hold true to the proposed "education hold harmless amount." Schools might also argue that the historical growth amount mentioned in the amendment is based on two fiscal years when state funds provided by the FEFP have been less than robust. Others may argue that reducing the amount of funds controlled by the school board reduces the importance of local control of the school system.

\section{Summary}

Adoption of the constitutional amendment requires a vote in favor of the amendment by a minimum of $60 \%$ of those voting. Additionally, amendments are subject to legal challenges and could possibly be removed from the ballot if successfully challenged.

Voters in Florida have the opportunity to change the state constitution during the 2008 general election. The intent and purpose of the information contained in this fact sheet on Amendment No. 5 is not to tell individuals how to vote. Rather, the fact sheet is provided to help voters become more informed. Informed voters need to be more knowledgeable of the ballot issue on which they are voting than just by reading a ballot title and ballot summary. Ballot titles and summaries do not inform voters in significant detail, nor do they inform voters on policy implications of what a yes or no vote implies. Because informed voters make informed public policy decisions, your challenge as a voter and a citizen is to become informed and then, by casting your ballot, make your values and preferences known.

\section{References}

Florida Department of State, Division of Elections. 2008. Initiatives / Amendments / Revisions. Division of Elections, Florida Department of State, Tallhassee, FL (May). http://election.dos.state.fl.us/initiatives/ initiativelist.asp

Florida Taxation and Budget Reform Commission. 2008. A resolution proposing an amendment to Sections 4 and 9 and the creation of Section 19 of Article VII and Section 28 of Article XII of the State Constitution. TBRC, Tallahassee, FL (May).

http://www.floridatbrc.org/pdf/CP2E2Final2.pdf

Florida Taxation and Budget Reform Commission. 2008. Staff Analysis and Economic Impact Statement. TBRC, Tallahassee, FL (May). http://www.floridatbrc.org/pdf/ 3_28_08SDCS_CP0002FirstEngrossedStaffAnalysis. pdf

Florida Taxation and Budget Reform Commission. 2008. Transmittal letter. TBRC, Tallahassee, FL (May). http://www.floridatbrc.org/pdf/ CPTransmittalLetter.pdf 